\title{
Headache and Its Effects on Health-Related Quality of Life Among Adults
}

\section{Erişkinlerde Baş Ağrusı ve Baş Ağrusınm Yaşam Kalitesi Üzerine Etkileri}

\author{
Didem ARSLANTAS ${ }^{1}$, Mustafa TOZUN ${ }^{1}$, Alaettin UNSAL ${ }^{1}$, Zuhtu OZBEK ${ }^{2}$ \\ ${ }^{1}$ Eskisehir Osmangazi University, Faculty of Medicine, Department of Public Health, Eskisehir, Turkey \\ ${ }^{2}$ Eskisehir Osmangazi University, Faculty of Medicine, Department of Neurosurgery, Eskisehir, Turkey
}

Corresponding Author: Zuhtu OZBEK / E-mail: zuhtuozbek@gmail.com

\begin{abstract}
AIM: This study was conducted with aim of determining prevalence of headache and evaluating its effects on health-related quality of life (HRQoL) in Beylikova town of Eskisehir city in the west of Turkey.

MATERIAL and METHODS: This study was conducted on adults aged 20 years and over aged between May11 and June04 2009 in Beylikova town of Eskisehir city in the west of Turkey. A total of 587 people were selected by simple randomized method. The International Headache Society criteria were used for the determination of severity of headache. The 36-item short-form (SF-36) was used for the assessment of healthrelated quality of life.

RESULTS: The number of men and women was 302 (51.4\%), and 285 (48.6\%), respectively. The mean age was $46.70 \pm 15.26$ years (range, $20-87$ years). Headache prevalence was found to be $78.2 \%(n=459)$. Decreased headache prevalence was found in the ages older than $30-44$ age group $(\mathrm{p}<0.05)$. All domains of SF-36, the mean scores were higher in individuals without headache than those with headache (for each, $p<0.05)$. Migraine prevalence was found to be $7.2 \%(n=33)$.
\end{abstract}

CONCLUSION: In accordance with the literature, this study found the presence of headache in adults at high frequency (78.2\%). Particularly the presence of migraine and increased severity of headache were found to decrease the quality of life.

KEYWORDS: Headache, Prevalence, SF-36, Population based study

öz

AMAÇ: Bu çalışma, Türkiye'nin batısında Eskişehir ilinin Beylikova kasabasında başağrısı prevalansını belirlemek ve başağrısının sağlıkla ilişkili yaşamkalitesi (SIYK) üzerine etkilerini değerlendirmek amacıyla yapılmıştır.

YÖNTEM ve GEREÇLER: Bu çalışma, Türkiyenin batısında Eskişehir ilinin Beylikova kasabasında 11 Mayıs - 4 Haziran 2009 tarihleri arasında 20 yaş ve üzeri erişkinlerde yapıldı. Basit rastgele örnekleme yöntemiyle toplam 587 kişi seçildi. Baş ağrısı şiddetinin belirlenmesi için Uluslararası Başağrısı Derneği kriterleri kullanıldı. 36-maddeli kısa form (KF-36) sağlıkla ilişkili yaşam kalitesinin değerlendirilmesi için kullanıldı.

BULGULAR: Kadın ve erkek sayısı sırasıyla 302 (\% 51.4) ve 285 (\% 48.6) idi. Yaş ortalaması 46.70 15.26 (aralık 20-87 yaş) idi. Baş ağrısı prevalansı \%78.2 ( $n=459$ ) olarak tespit edilmiştir. 30-44 yaş grubundan daha yaşlı olanlarda başağrısı prevalansı azalmış olarak $(p<0.05)$ bulundu. Tüm gruplarda SF-36 ortalama puanları baş ağrısı olmayan bireylerde baş ağrısı olanlardan (her biri için, $\mathrm{p}<0.05$ ) yüksek bulunmuştur. Migren prevalansı \% $7.2(n=33)$ olarak bulunmuştur.

SONUÇ: Bu çalışmada, literatüre uygun olarak yetişkinlerde başağrısı yüksek sıklıkta (\%78.2) bulunmuştur. Özellikle migren varlığı ve başağrısının artan şiddetinin yaşam kalitesini azaltığı bulunmuştur.

ANAHTAR SÖZCÜKLER: Başağrısı, Prevelans, SF-36, Nüfus tabanlı çalışma

\section{INTRODUCTION}

Headache is one of the most common disorders of the nervous system and several of its subtypes including tensiontype headache, migraine, cluster headache and the so-called chronic daily headache syndromes cause substantial levels of disability (38). Epidemiological studies of headache have been ongoing for more than 50 years (18). Primary types of headache including tension-type headache and migraine affect $80 \%$ of general population all over the world and are often a lifelong problem (36). Headache, particularly migraine, has been associated with decreased quality of life as well as with increased incidence of depression, stroke and disability. Prevalence of headache is higher in women than men, and the highest incidence is between the ages of 25 and 55 (4).

According to the World Health Organization (WHO), migraine alone is 19th among all causes of years lived with disability. Headache disorders impose recognizable burden on sufferers sometimes including substantial personal suffering, impaired quality of life and financial cost. Repeated headache attacks, and often the constant fear of the next one, impair family life, 
social life and employment. For example, social activity and work capacity are reduced in almost all migraine sufferers and in $60 \%$ of tension-type headache sufferers (45).

This study was conducted with aim of determining the prevalence of headache and evaluating its effects on healthrelated quality of life (HRQoL) in the Beylikova town of Eskisehir city in the west of Turkey.

\section{MATERIAL and METHODS}

This descriptive study was conducted on adults aged 20 years and over aged between May 11 and June 04, 2009 in Beylikova town of Eskisehir city in the west of Turkey. Total population of Beylikova town center was 3600 people; of them, 1784 (49.6\%) were men and 1816 (50.4\%) were women according to the health registers of Beylikova Community Health Center in 2009. Of the total population, $74.5 \%(n=2681)$ were adults aged 20 years and over.

Sample size was estimated to be approximately 600 people using a $3 \%$ margin of error, $95 \%$ confidence level and $80 \%$ response distribution of headache. A total of 587 people were selected by simple randomized method, and they accepted to participate in the study so they comprised the study group. Verbal consent was obtained from all individuals in the study group.

A questionnaire form was prepared in accordance with the literature $(11,32,46)$, and it included the questions regarding some socio-demographic characteristics (e.g., age, sex, educational level, job status, marital status, insurance), and the history of headache.

The International Headache Society criteria (29) were used for the determination of severity of headache.

The 36-item short-form (SF-36) was used for the assessment of HRQoL. The SF-36 was established by Ware and Sherbourne (42) in 1992. Validity and reliability study for SF-36 was conducted by Koçyigit et al. (21) in Turkey in 1999. The SF36 comprises of a multi-item scale that assesses eight health concepts: 1) physical functioning; 2) role limitations due to physical health; 3) social functioning; 4) bodily pain; 5) mental health (psychological distress and well-being); 6) role limitations due to emotional problems; 7) vitality (energy and fatigue); and 8) general health perceptions. Each domain is scored between 0 and 100 . The increasing domain scores indicate the increased quality of life (42).

A questionnaire form, the questions related to the International Headache Society criteria, and SF-36 questions were applied with face-to-face interviews to the individuals for data collection. Each interview lasted about 20 minutes.

The individuals suffering from a headache at least once within the last one year were classified as "individuals with headache".

The diagnosis of migraine was made with the ID Migraine Screener (19). Other headache types were not classified.
Individuals with headache were categorized into mild, moderate, and severe headache according to the blockage of daily activities.

The data were analyzed in SPSS 15.0 statistical pocket program. Chi square test, student's $t$-test, and One-Way ANOVA were used for statistical analyses. $p<0.05$ value accepted as statistical significance.

\section{RESULTS}

The number of men and women was 302 (51.4\%), and 285 (48.6), respectively. The mean age was $46.70 \pm 15.26$ years (range, 20-87 years) in this study group. Distribution of the age groups was as follows: 84 (14.3\%) individuals were aged under 30 years, 208 (35.4\%) individuals were in 30-44 age group, 157 (26.7\%) individuals were in 45-59 age group, and $138(23.5 \%)$ individuals were aged 60 years and over.

The number of individuals whose educational level were primary school and under were 360 (61.3\%), and 442 (75.3\%) were married. The number of unemployed individuals was $238(40.5 \%), 100$ (17.0) individuals were farmers, and 59 (10.1\%) were uninsured.

The prevalence of headache was found to be $78.2 \%(n=459)$. Headache prevalence was higher in women than in men (82.1\% vs. $74.5 \%)$.

The characteristics of individuals with/without headache are presented in Table I.

For all domains of SF-36 (except for social functioning), the mean scores were higher in individuals without headache than those with headache (for each, $\mathrm{p}<0.05$ ).

The mean scores on SF-36 domains according to the presence of headache are presented in Table II.

The number of mild/ moderate/ severe headache was 186 (40.5\%), 152 (33.1\%), and 121 (26.4\%), respectively. For all domains of SF-36 (except for social functioning), the mean scores increased with decreasing severity of the headache (for each, $\mathrm{p}<0.05$ ).

In this study, the number of individuals with migraine was 33 (7.2\%).

The mean scores of individuals with headache on SF-36 domains according to the presence of migraine headache are presented in Table III.

For physical functioning, role-physical, bodily pain, vitality, and mental health domains of Sf-36, the mean scores were higher in individuals without migraine than those with migraine (for each, $\mathrm{p}<0.05$ ).

The relationship of the severity of headache with the mean scores of SF-36 domains is presented in Table IV.

\section{DISCUSSION}

In this study, the incidence of headache was found to be $78.2 \%$. In the study of Stovner and colleagues (38) on the 
global burden of headache, the authors have discussed the results obtained from studies conducted in various countries around the world. Among them, the recent studies that have a similar methodology with our study are as follows: for Asian countries, $8.0 \%$ in Saudi Arabia (1), 28.5\% in Japan and ranging from $62 \%$ to $82.7 \%$ in other countries $(3,11,16$,
33, 41); for European countries, $29.0 \%$ in Greece (27), $29.2 \%$ in France (15), 37.7\% in Norway (14) and ranging from $49.4 \%$ to $86.7 \%$ in other countries $(10,13,23,24,47)$; for North and South American countries, $13.4 \%$ and $59.7 \%$ respectively in the United States (22, 34), 28.7\% in Peru (17), 63.1\% in Brazil (43), and $87.3 \%$ in Canada(28). The results of all these studies

Table I: The Characteristics of Individuals with/without Headache

\begin{tabular}{|c|c|c|c|c|}
\hline \multirow[b]{2}{*}{ Sociodemographics } & \multicolumn{3}{|c|}{ Headache } & \multirow[b]{2}{*}{$\begin{array}{l}\text { Statistical analysis } \\
X^{2} ; p \text { value }\end{array}$} \\
\hline & $\begin{array}{c}\text { No } \\
\text { n }(\%)^{*}\end{array}$ & $\begin{array}{c}\text { Yes } \\
\text { n }(\%)^{*}\end{array}$ & $\begin{array}{c}\text { Total } \\
\text { n }(\%)^{* *}\end{array}$ & \\
\hline \multicolumn{5}{|l|}{ Sex } \\
\hline $\begin{array}{l}\text { Women } \\
\text { Men }\end{array}$ & $\begin{array}{l}51(17.9) \\
77(25.5)\end{array}$ & $\begin{array}{l}234(82.1) \\
225(74.5)\end{array}$ & $\begin{array}{l}285(48.6) \\
302(51.4)\end{array}$ & $4.970 ; 0.026$ \\
\hline \multicolumn{5}{|l|}{ Age group (years) } \\
\hline $\begin{array}{l}<30 \\
30-44 \\
45-59 \\
\geq 60\end{array}$ & $\begin{array}{l}13(15.5) \\
29(13.9) \\
39(24.8) \\
47(34.1)\end{array}$ & $\begin{array}{r}71(84.5) \\
179(86.1) \\
118(75.2) \\
91(65.9)\end{array}$ & $\begin{array}{r}84(14.3) \\
208(35.4) \\
157(26.7) \\
138(23.5)\end{array}$ & $22.514 ;<0.001$ \\
\hline \multicolumn{5}{|l|}{ Education level } \\
\hline $\begin{array}{l}\text { Secondary school or below } \\
\text { High school or over }\end{array}$ & $\begin{array}{l}98(22.1) \\
30(21.0)\end{array}$ & $346(77.9)$ & $444(75.6)$ & $0.076 ; 0.783$ \\
\hline \multicolumn{5}{|l|}{ Marital status } \\
\hline $\begin{array}{l}\text { Married } \\
\text { Unmarried } \\
\text { Widowed }\end{array}$ & $\begin{array}{r}103(23.3) \\
7(11.5) \\
18(21.4)\end{array}$ & $\begin{array}{r}339(76.7) \\
54(88.5) \\
66(78.6)\end{array}$ & $\begin{array}{r}442(75.3) \\
61(10.4) \\
84(14.3)\end{array}$ & $4.406 ; 0.110$ \\
\hline \multicolumn{5}{|l|}{ Employment status } \\
\hline $\begin{array}{l}\text { Employment } \\
\text { Unemployment }\end{array}$ & $\begin{array}{l}71(20.3) \\
57(23.9)\end{array}$ & $\begin{array}{l}278(79.7) \\
181(76.1)\end{array}$ & $\begin{array}{l}349(59.5) \\
238(40.5)\end{array}$ & $1.079 ; 0.299$ \\
\hline \multicolumn{5}{|l|}{ Social insurance } \\
\hline $\begin{array}{l}\text { No } \\
\text { Yes }\end{array}$ & $\begin{array}{r}9(15.3) \\
119(22.5)\end{array}$ & $\begin{array}{r}50(84.7) \\
409(77.5)\end{array}$ & $\begin{array}{r}59(10.1) \\
528(89.9)\end{array}$ & $1.252 ; 0.263$ \\
\hline Total & $128(21.8)$ & 459 (78.2) & $587(100.0)$ & \\
\hline
\end{tabular}

*Percent for the row, **Percent for the column.

Table II: The Mean Scores on SF-36 Domains According to the Presence of Headache

\begin{tabular}{|c|c|c|c|}
\hline \multirow{3}{*}{ Domains } & \multicolumn{2}{|c|}{ SF-36 score } & \multirow{3}{*}{$\begin{array}{c}\text { Statistical analysis } \\
\text { t test; p-value }\end{array}$} \\
\hline & \multicolumn{2}{|c|}{ Headache } & \\
\hline & Yes $(n=459)$ (mean $\pm S d)$ & No $(n=128)($ mean $\pm S d)$ & \\
\hline Physical functioning & $79.00 \pm 27.27$ & $84.61 \pm 23.32$ & $2.121 ; 0.034$ \\
\hline Role-physical & $42.70 \pm 28.98$ & $52.47 \pm 24.93$ & $3.473 ; 0.001$ \\
\hline Bodily pain & $54.76 \pm 25.00$ & $73.13 \pm 26.38$ & $7.260 ; 0.000$ \\
\hline General health perception & $49.85 \pm 18.23$ & $58.55 \pm 17.83$ & $4.794 ; 0.000$ \\
\hline Vitality & $47.43 \pm 17.64$ & $56.88 \pm 19.18$ & $5.223 ; 0.000$ \\
\hline Social functioning & $53.56 \pm 11.64$ & $54.35 \pm 9.33$ & $0.706 ; 0.480$ \\
\hline Role-emotional & $58.32 \pm 45.20$ & $76.04 \pm 41.40$ & $3.994 ; 0.000$ \\
\hline Mental health & $55.24 \pm 16.15$ & $65.56 \pm 18.09$ & $6.225 ; 0.000$ \\
\hline
\end{tabular}


Table III: The Mean Scores of Individuals with Headache on SF-36 Domains According to the Presence of Migraine Headache

\begin{tabular}{|c|c|c|c|}
\hline \multirow{3}{*}{ Domains } & \multicolumn{2}{|c|}{ SF-36 score } & \multirow{3}{*}{$\begin{array}{c}\text { Statistical analysis } \\
\text { t test; p-value }\end{array}$} \\
\hline & \multicolumn{2}{|c|}{ Migraine headache } & \\
\hline & Yes (n=33) (mean $\pm S d)$ & No $(n=426)($ mean $\pm S d)$ & \\
\hline Physical functioning & $60.91 \pm 34.94$ & $80.40 \pm 26.12$ & $4.020 ; 0.000$ \\
\hline Role-physical & $29.80 \pm 30.83$ & $43.70 \pm 28.63$ & $2.673 ; 0.008$ \\
\hline Bodily pain & $39.33 \pm 21.27$ & $55.96 \pm 24.89$ & $3.733 ; 0.000$ \\
\hline General health perception & $44.89 \pm 18.78$ & $50.23 \pm 18.15$ & $1.627 ; 0.105$ \\
\hline Vitality & $36.82 \pm 16.99$ & $48.31 \pm 17.44$ & $3.653 ; 0.000$ \\
\hline Social functioning & $53.52 \pm 11.52$ & $54.11 \pm 13.25$ & $0.281 ; 0.779$ \\
\hline Role-emotional & $44.44 \pm 47.63$ & $59.39 \pm 44.89$ & $1.835 ; 0.067$ \\
\hline Mental health & $49.24 \pm 15.29$ & $55.70 \pm 16.14$ & $2.223 ; 0.027$ \\
\hline
\end{tabular}

Table IV: The Relationship of the Severity of Headache with the Mean Scores of SF-36 Domains

\begin{tabular}{|c|c|c|c|c|}
\hline \multirow[b]{3}{*}{ Domains } & \multicolumn{3}{|c|}{ SF-36 score } & \multirow{3}{*}{$\begin{array}{c}\text { Statistical analysis } \\
\text { F test; p- value }\end{array}$} \\
\hline & \multicolumn{3}{|c|}{ Severity oh headache } & \\
\hline & $\begin{array}{l}\text { Mild }(n=186) \\
(\text { mean } \pm S d)\end{array}$ & $\begin{array}{l}\text { Moderate }(n=152) \\
\quad(m e a n \pm S d)\end{array}$ & $\begin{array}{l}\text { Severe }(n=121) \\
(\text { mean } \pm S D)\end{array}$ & \\
\hline Physical functioning & $86.99 \pm 21.58$ & $81.61 \pm 23.65$ & $63.43 \pm 32.63$ & $32.277 ;<0.001$ \\
\hline Role-physical & $51.79 \pm 24.32$ & $44.63 \pm 28.23$ & $26.31 \pm 29.79$ & $32.851 ;<0.001$ \\
\hline Bodily pain & $65.09 \pm 20.78$ & $55.11 \pm 23.58$ & $38.44 \pm 24.22$ & $50.718 ;<0.001$ \\
\hline General health perception & $54.64 \pm 18.03$ & $48.48 \pm 17.78$ & $44.22 \pm 17.31$ & $13.301 ;<0.001$ \\
\hline Vitality & $53.41 \pm 17.49$ & $46.65 \pm 16.81$ & $39.42 \pm 15.48$ & $25.840 ;<0.001$ \\
\hline Social functioning & $53.99 \pm 10.61$ & $52.91 \pm 11.01$ & $53.72 \pm 13.80$ & $0.374 ; 0.688$ \\
\hline Role-emotional & $66.85 \pm 43.36$ & $60.09 \pm 43.91$ & $42.98 \pm 46.04$ & $10.844 ;<0.001$ \\
\hline Mental health & $59.25 \pm 17.08$ & $53.21 \pm 14.56$ & $51.62 \pm 15.34$ & $10.396 ;<0.001$ \\
\hline
\end{tabular}

show that the frequency of headache in adults has a wide range with being a significantly high value. In the study of Ertas et al (12) conducted in 21 provinces in Turkey with 5323 participants, the authors have reported the incidence of headache recurrence within 1 year as $44.6 \%$. In a study (5) conducted in 2008 in a resort in the province of Eskisehir, which was the study field of this study, the incidence of headache has been reported to be $71.5 \%$. The other studies $(6,35)$ conducted in Turkey have reported higher prevalence of headache, ranging from $65.9 \%$ to $92.0 \%$. These differences found in the prevalence of headache may be related to the different methodologies used in the studies. Because our results show a high prevalence of headache, it can be considered as compatible with the literature.

In our study, the prevalence of migraine was found to be 7.2\%. The American Migraine Prevalence and Prevention study (25) was a massive population-based epidemiological study (including a random sample of 77,879 households), and reported the 1-year female and male prevalence as $17.1 \%$ and $5.6 \%$, respectively. In the studies from Turkey, migraine prevalence has been reported to be $12.5 \%$ by Kececi et al (20) and $19.9 \%$ by Celik et al. (8). The lower prevalence of migraine found in this study compared to others may be explained by the fact that our study field was a rural area.

The incidence of headache in women in the study group was significantly higher than men $(p<0.05)$. There is evidence in the literature supporting our results. In almost all epidemiological studies from all over the world, the incidence of headache has been reported to be higher in women than men $(1,5,10,12$, $14,15,16,17,24,27,39,41,43)$. All the studies $(12,37)$ have revealed that migraine is two or three times more common in females than males. Sex hormones can completely explain this difference; there is substantial evidence that there may be a connection between migraine and the fluctuations in estrogen levels in women. The problem appears to be the response of the central nervous system to normal hormonal fluctuations (9). On the other hand, Tension Type Headache alone affects two-thirds of adult males and over $80 \%$ of females in developed countries (44). The causes of tension headaches also include emotional and mental stress, depression, and anxiety (40). Females have been reported to be more exposed to life-long stress, depression and anxiety, which may explain the higher prevalence of tension type headache in females. 
In our study, the incidence of headache is the highest in the 30-34 years age group and it decreased in older age groups $(p<0.05)$. Ayranci et al. (5) have reported similar results. This may be explained by decreased frequency of migraine due to the reduction of stress factors (40), particularly with quitting career and retiring as well as due to entering the menopause age in women (9). The prevalence of headache was not significantly different between the individuals with middle school or less education level and those with high school or higher education level ( $p>0.05$ ). Ayranci et al. (5) have also found no relationship between headache prevalence and the educational level. In a study from Brazil (31), tensiontype headache has been reported to be more common in individuals with more than 11 years of education.

Marital status, job-related stress factors and the anxiety and stress that would be related to the lack of social insurance are the factors that could affect the presence of headaches. Literature studies, however, reveal the opposite results. Queiroz et al (31) found no relationship between tensiontype headaches and marital status and employment status. Similarly, Ayranci et al (5) also reported no relationship between headache and marital status, employment status, and social insurance status. However, in another study of Queiroz et al (30), the prevalence of headache or migraine has been reported to be higher in individuals who are unemployed and who have low income level. We also did not find any difference between the head ache and marital status, employment status, and social insurance status (for each, $p>0.05$ ). This can be partly explained by the fact that social life in the study region with rural properties is more convenient to a regular life style.

In this study, the mean scores on all domains of SF-36 scale except for "social functioning" domain were significantly lower in individuals with headache compared to those without (for each domain, $\mathrm{p}<0.05)$. Among the individuals with headache, the mean scores on all domains of SF-36 scale except for general health perception, social functioning and roleemotional domains were significantly lower in those suffering from migraine than those without migraine (for each domain, $p<0.05)$. These results provide evidence that the presence of headache and particularly of migraine impairs the quality of life. There are many researchers supporting our study findings. Ayranci et al (5) reported significantly lower mean scores on all domains of SF-36 in individuals with headache than those without. Similarly, Akhmadeeva et al (30) have reported that the scores on all domains of SF-36 were lower in those with headache. Bingefors and Isacson (7) have indicated that the physical dimensions of HRQoL were more affected by headache among men, and that psychological dimensions were more affected among women. Mannix et al (26) have also notified that those with headache had lower HRQoL in the bodily pain, vitality and mental health domains of the SF-36. All of these results suggest that headache impairs the HRQoL.
In our study group, the mean scores on all domains of SF-36 except for those on social functioning domain were decreased with the increasing severity of headache (for each domain, $p<0.05)$. This suggests that the quality of life decreases with the increasing severity of headache. Ayranci et al. (5) have also reported similar results in their study.

\section{LIMITATIONS}

The major limitations of this study are that it was conducted in a relatively small region, the headache types other than migraine were not classified, and studying only one sample could lead to possible sample selection errors.

\section{CONCLUSION}

In accordance with the literature, the prevalence of headache in adults was found to be higher in this study (78.2\%). The presence of headache, especially the migraine, and the increased severity of headache were found to decrease the quality of life. Seeking and implementing effective intervention and counseling programs would help to improve the HRQoL in rural areas and further studies are warranted in this field.

\section{REFERENCES}

1. Abduljabbar M, Ogunniyi A, Al Balla S, Alballaa S, Al-Dalaan A: Prevalence of primary headache syndrome in adults in the Qassim region of Saudi Arabia. Headache 36:385-388, 1996

2. Akhmadeeva LR, Magzhanov RV, Zakirova EN, Abdrashitov TM, Samigullina GD: Quality of life of patients with primary headaches, strokes and myotonic dystrophy. Zh Nevrol Psikhiatr Im S S Korsakova 108:72-75, 2008

3. Alders EE, Hentzen A, Tan CT: A community-based prevalence study on headache in Malaysia. Headache 36:379-384, 1996

4. Molarius A, Tegelberg A, Öhrvik J: Socio-economic factors, lifestyle, and headache disorders - A population-based study in Sweden. Headache 48:1426-1437, 2008

5. Ayranci $U$, Tozun $M$, Unsal A: Headache among adults and its effect on quality of life in a town of Western Turkey. Pak J Med Sci 27(4):775-779, 2011

6. Baykan B, Ertas M, Karli N, Akat-Aktas S, Uzunkaya O, Zarifoglu M, Siva A, Saip S: MIRA-Neurology Study Group. The burden of headache in neurology outpatient clinics in Turkey. Pain Pract 7:313-323, 2007

7. Bingefors K, Isacson D: Epidemiology, co-morbidity, and impact on health-related quality of life of self-reported headache and musculoskeletal pain-a gender perspective. Eur J Pain 8:435-450, 2004

8. Celik Y, Ekuklu G, Tokuc B, Utku U: Migraine prevalence and some related factors in Turkey. Headache 45:32-36, 2005

9. Cornforth T: Why women have more migraines: The role of hormones. http://womenshealth.about.com/cs/ headaches/a/migranes1.htm

10. Dahlof $C$, Linde $M$ : One-year prevalence of migraine in Sweden: A population-based study in adults. Cephalalgia 21:664-671, 2001 
11. Deleu D, Khan MA, Al Shehab TA: Prevalence and clinical characteristics of headache in a Rural Community in Oman. Headache 42(10):963-973, 2002

12. Ertas M, Baykan B, Orhan EK, Zarifoglu M, Karli N, Saip S, Onal $A E$, Siva $A$ : One-year prevalence and the impact of migraine and tension-type headache in Turkey: A nationwide homebased study in adults. J Headache Pain 13(2):147-157, 2012

13. Gobel H, Petersen-Braun M, Soyka D: The epidemiology of headache in Germany: A nationwide survey of a representative sample on the basis of the headache classification of the International Headache Society. Cephalalgia 14:97-106, 1994

14. Hagen K, Zwart JA, Vatten L, Stovner LJ, Bovim G: Prevalence of migraine and non-migrainous headache-head-HUNT, a large population-based study. Cephalalgia 20:900-906, 2000

15. Henry P, Auray JP, Gaudin AF, Dartigues JF, Duru G, LanteriMinet $M$, Lucas C, Pradalier A, Chazot G, El Hasnaoui A: Prevalence and clinical characteristics of migraine in France. Neurology 59:232-237, 2002

16. Ho KH, Ong BK: A community-based study of headache diagnosis and prevalence in Singapore. Cephalalgia 23:6-13, 2003

17. Jaillard AS, Mazetti $P$, Kala E: Prevalence of migraine and headache in a high-altitude town of Peru: A populationbased study. Headache 37:95-101, 1997

18. Junior AS, Krymchantowski A, Moreira $P$, Vasconcelos L, Gomez R, Teixeira A: Prevalence of headache in entire population of a small city in Brazil. Headache 49: 895-899, 2009

19. Karli N, Ertas M, Baykan B, Uzunkaya O, Saip S, Zarifoglu M, Siva A: MIRA study group. The validation of ID Migraine screener in neurology outpatient clinics in Turkey. J Headache Pain 8(4): 217-223, 2007

20. Kececi H, Dener S: Epidemiological and clinical characteristics of migraine in Sivas, Turkey. Headache 42:275-280, 2002

21. Kocyigit $\mathrm{H}$, Aydemir $\mathrm{O}$, Olmez N, Memis A: Reliability and validity of the Turkish version of Short-Form-36 (SF-36). Turkish J Drugs Therapy 12:102-106,1999

22. Kryst S, Scherl E: A population-based survey of the social and personal impact of headache. Headache 34:344-350, 1994

23. Laínez MJA, Vioque J, Hernández-Aguado I, Titus F: Prevalence of migraine in Spain. An assessment of the questionnaire's validity by clinical interview. In: Olesen J (ed), Frontiers in Headache Research: Headache Classification and Epidemiology, 4th ed. New York: Raven Press Ltd, 1994: 221225

24. Lampl C, Buzath A, Baumhackl U, Klingler D: One-year prevalence of migraine in Austria: A nation-wide survey. Cephalalgia 23:280-286, 2003

25. Lipton RB, Bigal ME, Diamond M, Freitag F, Reed ML, Stewart WF; AMPP Advisory Group: Migraine prevalence, disease burden, and the need for preventive therapy. Neurology 68:343-349, 2007
26. Mannix LK, Chandurkar RS, Rybicki LA, Tusek DL, Solomon GD: Effect of guided imagery on quality of life for patients with chronic tension-type headache. Headache 39:326-334, 1999

27. Mitsikostas DD, Tsaklakidou D, Athanasiadis N, Thomas A: The prevalence of headache in Greece: Correlations to atitude and climatological factors. Headache 36:168-173, 1996

28. O'Brien B, Goeree R, Streiner D: Prevalence of migraine headache in Canada: A population-based survey. Int J Epidemiol 23:1020-1026, 1994

29. Olesen J, Steiner TJ: The international classification of headache disorders, 2nd ed (ICDH-II). J Neurol Neurosurg Psychiatry 75(6):808-811, 2004

30. Queiroz LP, Peres MF, Kowacs F, Piovesan EJ, Ciciarelli MC, Souza JA, Zukerman E: Chronic daily headache in Brazil: A nationwide population-based study. Cephalalgia 28: 1264-1269, 2008

31. Queiroz LP, Peres MF, Piovesan EJ, Kowacs F, Ciciarelli MC, Souza JA, Zukerman E: A nationwide population-based study of tension-type headache in Brazil. Headache 49(1):71-78, 2009

32. Quesada-Vázquez AJ, Contreras-Maure LJ, Alvarez-Aliaga A, Traba-Tamayo ER: Prevalence of primary headaches in a rural population in Cuba. Rev Neurol 49(3):131-135, 2009

33. Roh JK, Kim JS, Ahn YO: Epidemiologic and clinical characteristics of migraine and tension-type headache in Korea. Headache 38:356-365, 1998

34. Schwartz BS, Stewart WF, Simon D, Lipton RB: Epidemiology of tension-type headache. JAMA 279:381-383, 1998

35. Simsek Z, Kurcer MA, Yildiz A, Altin H: Applying for health Furnace Sanliurfa Tilfindir coping with headache and headache Behaviour Types. Hr Uni Tıp Fak Der 1:20-24, 2004

36. Steiner TJ: Lifting the burden: The global campaign to reduce the burden of headache worlwide. J Headache Pain 6: 373-377, 2005

37. Stovner LJ, Andree C: Prevalence of headache in Europe: A review for the Eurolight project. J Headache Pain 11(4): 289-299, 2010

38. Stovner LJ, Hagen $\mathrm{K}$, Jensen R, Katsarava Z, Lipton RB, Scher A, Steiner T, Zwart JA: The global burden of headache: Adocumentation of headache prevalence and disability worldwide. Cephalalgia 27:193-210, 2007

39. Takeshima T, Ishizaki K, Fukuhara $Y$, ljiri T, Kusumi M, Wakutani Y, Mori M, Kawashima M, Kowa H, Adachi Y, Urakami K, Nakashima K: Population-based door-to-door survey of migraine in Japan: The Daisen study. Headache 44:8-19, 2004

40. Tension headaches. http://www.medicinenet.com/tension_ headache/article.htm (Available date: 09.09.2012)

41. Wang SJ, Fuh JL, Lu SR, Liu CY, Hsu LC, Wang PN, Liu HC: Chronic daily headache in Chinese elderly: Prevalence, risk factors, and biannual follow-up. Neurology 54:314-319, 2000

42. Ware JE, Sherbourne CD: The MOS 36-item short-form health survey (SF-36). I. Conceptual framework and item selection. Medical Care 30(6):473-483,1992 
43. Wiehe M, Fuchs SC, Moreira LB, Moraes RS, Fuchs FD: Migraine is more frequent in individuals with optimal and normal blood pressure: A population-based study. J Hypertens 20:1303-1306, 2002

44. WHO. Headache disorders. http://www.who.int/mediacentre/ factsheets/fs277/en/ (Available date: 09.09.2012). March, 2004

45. WHO.HeadacheDisorders.www.who.int/entity/mediacentre/ factsheets/fs277/en/ (Available date: 25.08.2012), 2004
46. Yokoyama M, Yokoyama T, Funazu K, Yamashita T, Kondo S, Hosoai H, Yokoyama A, Nakamura H: Associations between headache and stress, alcohol drinking, exercise, sleep, and comorbid health conditions in a Japanese population. J Headache Pain 10(3):177-185, 2009

47. Zivadinov R, Willheim K, Jurjevic A, Sepic-Grahovac D, Bucuk $M$, Zorzon M: Prevalence of migraine in Croatia: A populationbased survey. Headache 41:805-812, 2001 